\title{
Energy Harvesting for Wireless Sensor Networks Review
}

\author{
Saba Akbari \\ "MATI"- Russian State Technological University Orshanskaya 3, 121552 Moscow, Russia \\ Email: akbarisaba@gmail.com
}

\begin{abstract}
With the widespread use of wireless sensors, the management of their energy resources has become a topic of research. Wireless sensors usually use batteries as their power supply but in some applications battery replacement can be cumbersome and require considerable amount of time which can affect the process being monitored. It is possible to harvest energy from the sources in nature for wireless sensors. In this article, a review of current alternative energy sources has been demonstrated in order to address the feasibility of their integration with wireless sensor networks.
\end{abstract}

\section{INTRODUCTION}

$\mathrm{F}$ ire and toxic gas leakage may have consequences resulting in pecuniary loss or fatality. Monitoring of hazardous gases is one of the areas where wireless sensors have been used [1]. Systems based on wires have some disadvantages as being dependent on power supply, high maintenance costs, sometimes electrical power supply cut off occurrence, and long deployment time. The study of forest fires has been also considered as an important issue and since it may take place in some areas of difficult access, the development of wireless sensor technology can be applied in this field as well [2],[3]. Wildfire which occurs in the countryside or wilderness area is a topic which is not yet completely resolved [4]. The satellite technology and aircrafts can track such incidents. However, there are some advantages and disadvantages associated with each method. The deployment costs for using satellites are high [1] and due to the orbital limitations not all satellites can monitor a fire event continuously [5]. Limitations of using aircrafts can arise in some areas which are prone to low altitude clouds and this can cause more obstacles in terms of visibility [5]. Wireless sensors have become an interesting topic to tackle this issue [6],[7]. But this technology also has its own challenges. The high power consumption of combustible gas detection systems is a restricting factor which needs to be considered [8],[9]. Sensors designed for this purpose and having on board batteries cannot have a long time life cycle [1] and moreover in some applications like structural health monitoring of critical infrastructures and buildings, it is difficult to replace or recharge batteries [10]. As mentioned in [11], some sensor networks like BAN systems require low energy levels. Table 1, 2 and 3 illustrate some off- the- shell components used in sensor node design [12]. As it can be seen from Table 1, the current consumption of the gas sensors is higher in comparison with other components used in the sensor module. The operation time of the autonomous wireless sensor device is currently limited by the batteries capacity which is about $3000 \mathrm{mAh}, 8000 \mathrm{mAh}$ and 15000 $\mathrm{mAh}$ for the AA, C and D batteries types, respectively. Taking into account the high power consumption of sensor nodes, it is necessary to optimize the use of battery. Therefore, demands on response time require that the measurement of gas concentration for example of combustible gases be done no more than every $120 \mathrm{~s}$ [13]. Nature provides us with variety of energy sources which can be harvested and implemented for wireless sensor systems [14]. Some various sources which can provide the necessary amount of power include solar, piezoelectricity, thermal, wind, and radio frequency. A compilation of various energy harvesting sources is given in Table 4 [15].

\section{HARVESTING METHODS}

\section{A. Solar Energy}

Typically, a sensor node which uses energy from nature, consists of several blocks such as energy harvesting module, the storage unit such as a supercapacitor, sensing element, microcontroller and a transmitter as shown in Figure 1.

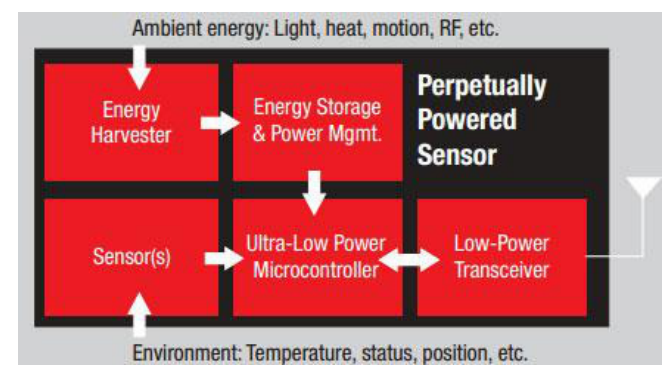

Fig. 1 Wireless sensor network with an energy harvesting module [16]

Photovoltaic is the technology that generates direct current from semiconductors when they are illuminated by photons. Most of the solar cells today are made of crystalline silicon (c-Si). Silicon has been the most widely used material in the production of photovoltaic modules. The mono- crystal, multi-crystal, micro-crystal and amorphous are the most widely used forms of silicon in the production of photovoltaic cells [17]. 
TABLE I.

POWER CONSUMPTION OF SOME OFF - THE - SHELF GAS SENSORS[12]

\begin{tabular}{|l|l|l|}
\hline \multicolumn{1}{|c|}{ TYPE } & \multicolumn{1}{c|}{ COMPANY } & POWER $(\mathbf{m W})$ \\
\hline $\begin{array}{l}\text { DTK-2 } \\
\text { Catalytic Sensor }\end{array}$ & NTC-IGD, Russia & $120 \mathrm{~mW}$ \\
\hline $\begin{array}{l}\text { SGS-21XX } \\
\text { Semiconductor } \\
\text { Sensor }\end{array}$ & Delta, Russia & $200 \mathrm{~mW}$ \\
\hline $\begin{array}{l}\text { TGS2610 } \\
\text { Semiconductor } \\
\text { Sensor }\end{array}$ & FIGARO, Japan & $280 \mathrm{~mW}$ \\
\hline $\begin{array}{l}\text { NAP-66A } \\
\text { Catalytic Sensor }\end{array}$ & Nemoto, Japan & $360 \mathrm{~mW}$ \\
\hline $\begin{array}{l}\text { MQ-4 } \\
\text { Semiconductor } \\
\text { Sensor }\end{array}$ & Hanwei & $750 \mathrm{~mW}$ \\
\hline
\end{tabular}

Nanotechnology based semiconductors including nanowires, nanocrystals, nanorods and nanodots have been opening a new perspective for scientists to design solar cells [18].

TABLE II.

CURRENT CONSUMPTION OF SOME OFF - THE SHELF TRANSCEIVERS[12]

\begin{tabular}{|l|l|l|}
\hline \multicolumn{1}{|c|}{ TYPE } & COMPANY & \multicolumn{1}{c|}{$\begin{array}{c}\text { CURRENT } \\
\text { CONSUMPTION } \\
\text { (mA) }\end{array}$} \\
\hline $\begin{array}{l}\text { CC2500 } \\
\text { Transciever }\end{array}$ & $\begin{array}{l}\text { Texas } \\
\text { Instruments }\end{array}$ & $\begin{array}{l}\text { Tx: } 21.2 \mathrm{~mA} @ 0 \\
\mathrm{dBm} \\
\mathrm{Rx}: 13.3 \mathrm{~mA}\end{array}$ \\
\hline $\begin{array}{l}\text { CC2430 } \\
\text { Trasnceiver }\end{array}$ & Texas & $\begin{array}{l}\text { Tx: } 27 \mathrm{~mA}, \mathrm{Rx}: 25 \\
\mathrm{~mA}\end{array}$ \\
\hline $\begin{array}{l}\text { ETRX35x } \\
\text { Transceiver }\end{array}$ & Telegesis & $\begin{array}{l}\text { Tx: } 31 \mathrm{~mA} @+3 \\
\mathrm{dBm}, \mathrm{Rx}: 25 \mathrm{~mA}\end{array}$ \\
& & $\begin{array}{l}\text { @ } 12 \mathrm{MHz} \text { clock } \\
\text { speed }\end{array}$ \\
\hline $\begin{array}{l}\text { TR1000 } \\
\text { Transceiver }\end{array}$ & RF Monolithics & $\begin{array}{l}\text { Tx: } 12 \mathrm{~mA} @ 0 \\
\mathrm{dBm}, \mathrm{Rx}: 3.1 \mathrm{~mA}\end{array}$ \\
\hline $\begin{array}{l}\text { JN5148-001-M00/03 } \\
\text { Transceiver Sensor }\end{array}$ & Jennic & $\begin{array}{l}\text { Tx: } 15 \mathrm{~mA} @+2.5 \\
\mathrm{dBm}, \mathrm{Rx}: 17.5 \mathrm{~mA}\end{array}$ \\
\hline
\end{tabular}

Solar energy can generate enough amount of power necessary for wireless sensors [19]. A solar panel is used as an energy harvesting source for the wireless sensor in [20].

Solar energy harvesting provides direct DC voltage and therefore additional circuit rectifications are not required. This type of energy scavenging is free of emissions since it does not produce contaminants or bypass products that are harmful to the environment [21].

One of the limitations of solar energy is its dependency on solar radiation, which can be degraded in areas where enough sunlight is not available. Solar energy is characterized by having a varying nature [22]. The other issue associated with solar cells and for which some research is ongoing is the cooling of solar cells and recovering heat [23].

TABLE III.

POWER CONSUMPTION OF SOME OFF - THE - SHELF COMPONENTS USED IN SENSOR NODE[12]

\begin{tabular}{|c|c|c|}
\hline TYPE & COMPANY & $\begin{array}{c}\text { CURRENT } \\
\text { CONSUMPTION }(\mathrm{mA})\end{array}$ \\
\hline $\begin{array}{l}\text { MSP430F247 } \\
\text { Microcontroller }\end{array}$ & $\begin{array}{l}\text { Texas } \\
\text { Instruments }\end{array}$ & $\begin{array}{l}\text { Active mode: } 321 \text { uA @ } 3 \\
\text { V / } 1 \mathrm{MHz} \\
\text { Low power mode: } 1 \text { uA @ } \\
\text { 3V / } 32768 \mathrm{~Hz}\end{array}$ \\
\hline $\begin{array}{l}\text { ATmega168P } \\
\text { Microcontroller }\end{array}$ & Atmel & $\begin{array}{l}\text { Active mode: } 1.8 \mathrm{~mA} @ 3 \\
\text { V / } 4 \mathrm{MHz} \\
\text { Power-save mode: } 0.9 \mathrm{uA} \\
\text { @ } 3 \mathrm{~V} / 32 \mathrm{kHz}\end{array}$ \\
\hline $\begin{array}{l}\text { ATxmega32A4 } \\
\text { Microcontroller }\end{array}$ & Atmel & $\begin{array}{l}\text { Active mode: } 1.1 \mathrm{~mA} @ 3 \\
\text { V / } 2 \mathrm{MHz} \\
\text { Power-save mode: } 0.7 \mathrm{uA} \\
\text { @ } 3 \mathrm{~V} / 32 \mathrm{kHz}\end{array}$ \\
\hline $\begin{array}{l}\text { ADuC824 } \\
\text { Microcontroller }\end{array}$ & $\begin{array}{l}\text { Analog } \\
\text { Devices }\end{array}$ & $\begin{array}{l}\text { Active mode: } 3 \mathrm{~mA} @ 3 \mathrm{~V} \\
/ 1.5 \mathrm{MHz} \\
\text { Power-down mode: } 20 \mathrm{uA} \\
\text { @ } 3 \mathrm{~V} / 32 \mathrm{kHz}\end{array}$ \\
\hline
\end{tabular}

\section{B. Piezoelectricity}

Piezoelectricity stems from the Greek word "piezo" for pressure and the word "electric" for electricity. The main advantage of piezoelectric materials as shown in Figure 2 is the high amount of voltage they can provide. Some materials which have piezoelectric effect are quartz, soft and hard lead ziconate titane piezoceramics (PZT-5H and PZT5A), barium titanate (BaTiO3) and polyvinylidene fluride (PVDF)[24].

In the piezoelectric effect the usable output voltage can be obtained directly from the material and there is no need for applying multistage post processing for generating the desired amount of voltage [25]. Piezoelectric materials require dynamic forces in order to retain the output voltage and a notable drawback of piezoelectric sensors is their inability to respond to static loads [26].

\section{Radio Energy}

The possibility of harvesting RF energy, from ambient, enables wireless charging of a sensor node [27].

Having a transmitter set, one can harvest energy from radio waves and the advantage of this alternative is the fact that the scavenging mechanism can be flexible and it is

TABLE IV

SOME ENERGY HARVESTING SOURCES [15],[16]

\begin{tabular}{|c|c|c|}
\hline Energy Source & Conditions & Performance \\
\hline Solar & Outdoors & $7500 \mu \mathrm{W} / \mathrm{cm}^{2}$ \\
\hline Solar & Indoors & $100 \mu \mathrm{W} / \mathrm{cm}^{2}$ \\
\hline Vibration & $1 \mathrm{~m} / \mathrm{s}^{2}$ & $100 \mu \mathrm{W} / \mathrm{cm}^{3}$ \\
\hline $\mathrm{RF}$ & $\mathrm{WiFi}$ & $0.001 \mu \mathrm{W} / \mathrm{cm}^{2}$ \\
\hline $\mathrm{RF}$ & $\mathrm{GSM}$ & $0.1 \mu \mathrm{W} / \mathrm{cm}^{2}$ \\
\hline Thermal & $\Delta \mathrm{T}=5^{\circ} \mathrm{C}$ & $60 \mu \mathrm{W} / \mathrm{cm}^{2}$ \\
\hline
\end{tabular}


possible to control the amount of transferred energy by making it continuous i.e. on regular intervals or the amount of radiated energy can be adjusted according to the requirements of the relevant application [28].

It is necessary to note that, according to the Friis equation, the amount of power collected at the receiver side is not equal to the exact value sent by transmitter [29].

\section{Thermal Energy}

Thermal energy produces electricity when there is a temperature difference (Seebeck effect).

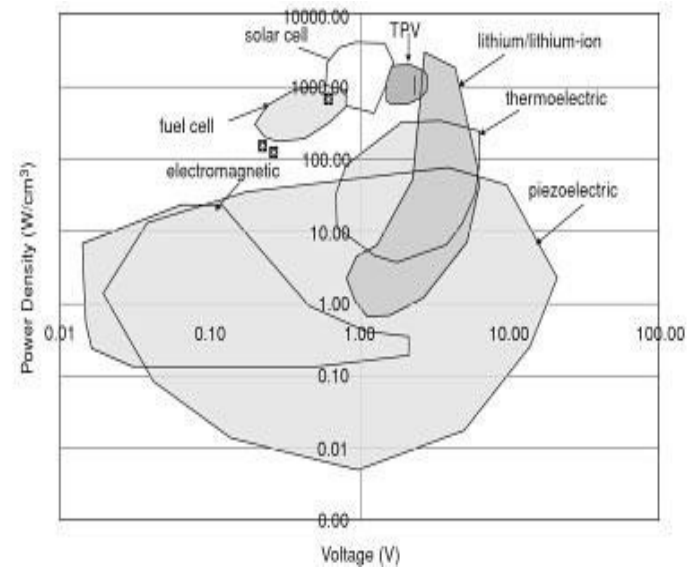

Fig. 2. The voltage generated by the piezoelectric material itself is greater than the value produced by some other harvesting sources [25]

Most thermoelectric generators consist of $\mathrm{n}$ type and $\mathrm{p}$ type an array of $\mathrm{p}$ - and n- type semiconductors in series. Heat from a hot source reaches the hot shoe and is conducted through to the semiconductors. The hot shoe has a high thermal conductivity and as well as a high electrical conductivity. Electrons are released from $\mathrm{n}$ type semiconductor and establish a current through $\mathrm{p}$ type semiconductor. Cold shoes transfer the current to the electric load [30].

Commercially available thermoelectric generators require a temperature difference of $10-200{ }^{\circ} \mathrm{C}$ [31].

This type of energy is able to provide supply DC power continuously but temperature differentials can be difficult to generate in enclosed environments [32].

\section{Wind Energy}

Among the various forms of existing renewable energy sources, wind energy is one of the remarkable sources in the macro scale for generating electricity. Countries like Germany, Spain and Denmark have provided a significant amount of their required electricity by using this type of energy.

Having evaluated the given possibilities in high power electronics, its application can be also surveyed for miniaturized devices.
In the study presented in [33], different wind turbine blade configurations (two, three and six blade propellers) within a wind speed interval of 3.5 to $7 \mathrm{~m} / \mathrm{s}$ were tested. The propeller with six blades output the maximum power. The authors propose to add a solar panel to the harvesting system in case the amount of energy provided by wind energy will not suffice.

During the analysis of alternative sources for wireless sensor networks, an experiment to survey the feasibility of using wind energy as a complementary system for wireless sensor systems was performed. In this experiment, two types of blades were tested. The measured wind speed was $3.7 \mathrm{~m} / \mathrm{s}$ and $4.5 \mathrm{~m} / \mathrm{s}$. In the first case, the length of each blade was $4.35 \mathrm{~cm}$ and in the second one, it corresponded to $8.85 \mathrm{~cm}$.

Figure 3.a shows power generated by the wind turbine as a function of load. The peak power for the propeller with smaller blades at the speed of $4.5 \mathrm{~m} / \mathrm{s}$ is $7.2 \mathrm{~mW}$.

At $3.7 \mathrm{~m} / \mathrm{s}$, the peak value of power for the first type of blade is $5.5 \mathrm{~mW}$ and for the second type of blade, the maximum amount of power at the speed of $4.5 \mathrm{~m} / \mathrm{s}$ is approximately $5.5 \mathrm{~mW}$ (Figure 3.a). As the rotor of the DC motor starts rotating, the $\mathrm{AC}$ current flows in the circuit which consists of motor windings and the load.

As a result of this, self induction takes place. This effect can be seen in Figure $3 \mathrm{a}$ and $\mathrm{b}$ for the first type of propeller when the load resistance is less than $500 \mathrm{Ohm}$ and in the meantime the experimental points and the approximation do not converge. The experiment indicates that a microturbine based on a DC motor can be represented as a voltage source and an internal resistance according to the Thevenin theorem. Two factors which have caused less amount of power in our experiment in comparison with [33] are the wind speed and motor. It can be also observed from Figure 3.a that the larger propeller provides maximum output at smaller values of load $(\sim 60 \mathrm{ohm})$ and the smaller one reaches its power peak values at higher loads $(\sim 250 \mathrm{ohm})$, i.e. depending on the load value, the necessary blade can be chosen.

This model is valid only in cases when the induced current is greater than the self induction current. Wind is a free energy that nature provides us and there is no limit in using it. It produces no polluting emissions of any kind [34]. Wind energy in some environments cannot be considered as a primary source for electricity generation due to its intermittent behavior which causes instability to the power system [34].

\section{APPLICATIONS}

Alternative sources can be used along with batteries as a complementary system or in case of existence of enough energy from the environment, they can be employed as primary power sources. Pipeline monitoring in industrial complexes is a remarkable example where wireless sensors can be deployed [35]. It is quite plausible to employ energy harvesting techniques as primary or secondary power 
supplies for the sensors in this scenario. In case of battery replacement, the harvesting technologies increase the possibility of continuous operation of the system and consequently the process will not be stopped.

Bridge health monitoring is another example discussed in [36]. In the Jindo bridge project, eight sensors out of 70 are equipped with solar panels. The charging process of the solar system is working well except one node which is not receiving enough sunlight due to its location. It is suggested that in the next deployment, either a more sensitive solar panel can be used or another type of energy harvesting may be considered [37].

\section{ENERGY STORAGE}

At the moment, batteries are still the most common way to provide energy for low electronic devices. The specifications of $\mathrm{Li}$ - ion and thin film batteries are shown in Table 5 .

The majority of wireless sensor networks are powered by batteries. As mentioned at the beginning of the article, the batteries used in wireless sensor networks have a finite lifetime which requires replacement or recharging.

Primary cells which cannot be recharged may cause a huge amount of work associated with replacement if used in a large network [38] like in the case of pipeline monitoring. Secondary batteries are rechargeable but they have a lower energy density than primary batteries [38].

The combination of an energy harvesting scheme with a rechargeable battery or with another storage system such as a thin film rechargeable battery or a supercapacitor can be implemented for wireless sensor networks. Figure 4 shows a comparison of several storage schemes. It is assumed that the volume of energy storage scheme is $1 \mathrm{~cm}^{3}$. If the energy consumption is $100 \mu \mathrm{W}$ then the operation time of the primary battery lasts just for only a few months. The combination of an energy harvester with a rechargeable battery ensures a long term operation of the system.

Developing this strategy maybe necessary since sometimes the output power from the energy harvesting due to their intermittent nature may not be enough to compensate for the current consumption at receive and transmit periods. This scenario is illustrated in Figure 5.

\section{CONCLUSION}

An overview of the alternative energy sources was presented in this review article and the experiment using wind energy demonstrated the potentiality of this source to power low electronic devices. It is necessary to note that systems for harvesting and storing energies shall be designed based on the combination of two or more sources of alternative energy. For instance, for those electronic systems performing outdoor, solar and wind energies can be considered as sources for powering the devices or in the case of low power electronic devices located indoor, radio waves and thermal energy can be designated.

The hybrid energy sources increase the probability of having uninterruptible power supply because each source can compensate some fluctuation of energy of its counterpart transmitted to the powered device.

In addition to the conventional applications of energy harvesting, this technology can be used in the concept of "Smart Homes" as well as the management and powering of real objects in the Internet of Things [40].

In order to optimize the harvesting process using this type of energy, the following points can be considered in the future research:

1. Implement a micro wind turbine model. This defines a system where one can enter an input parameter such as wind speed and blade radius and based on that the output power can be obtained.

2. Develop hybrid models in order to feed the sensor simultaneously from more than one source. As a result, more energy can be stored for the node and this leads to storing more energy as well as providing a more realistic battery less operation of the overall system

3. In order to ensure a continuous operation of the sensor,
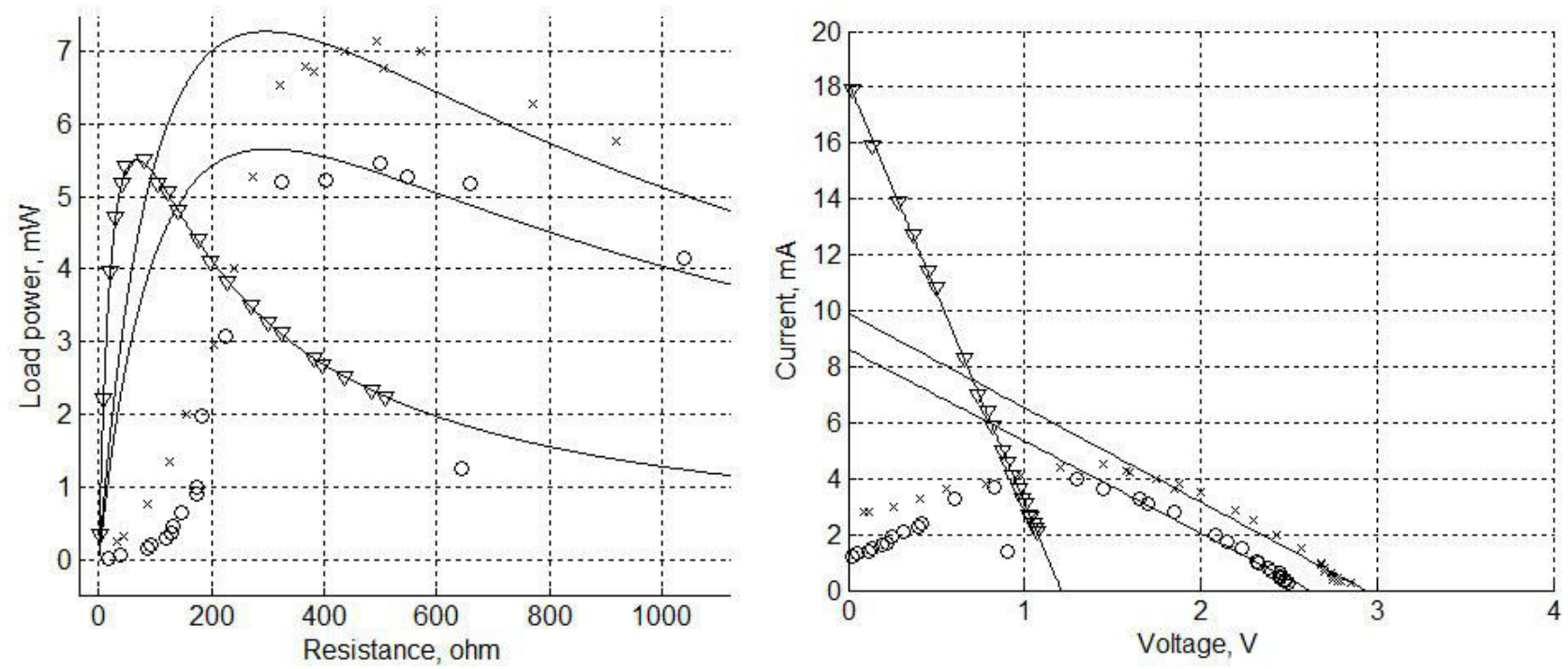

Fig.3. a) Power versus resistance for two types of propellers b) Current versus voltage for the same propellers $\mathrm{x}$ - Propeller with blade size of $4.35 \mathrm{~cm}$ at $4.5 \mathrm{~m} / \mathrm{s}$ o - Propeller with blade size of $4.35 \mathrm{~cm}$ at $3.7 \mathrm{~m} / \mathrm{s} \nabla-$ Propeller with blade size of $8.85 \mathrm{~cm}$ at $4.5 \mathrm{~m} / \mathrm{s}$ 
a combination of an energy storage scheme and the harvesting system may output a steady operation of the sensor node.

4. In terms of applications, a system composed of solar cell and micro wind turbine can be designated for pipeline monitoring since replacing batteries in these areas can take a long time and stop the process. In some areas which have enough sunlight and wind, this model can be applied to provide a continuous operation of sensors.

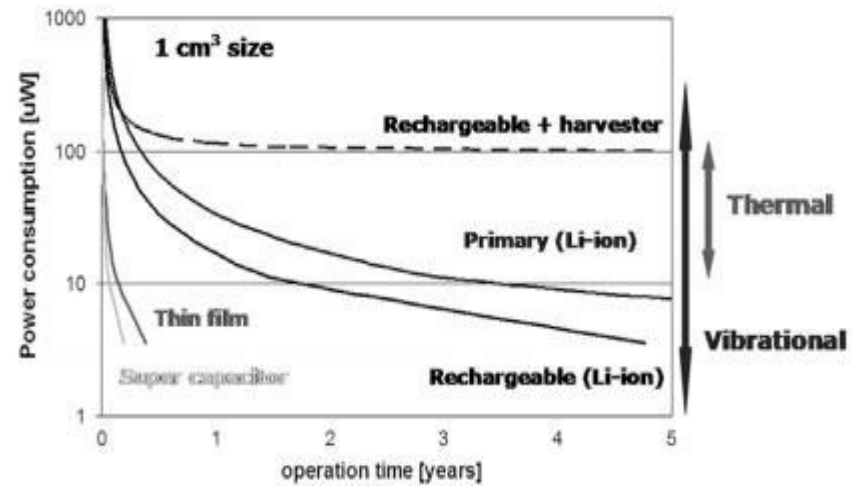

Fig. 4. A comparison of the operation time versus power consumption of various storage systems [39]

5. Thermal energy harvesting has also gained popularity for powering microelctronic devices. This technology can be also used in pipeline monitoring as a source to power sensors in which case it is feasible to use the temperature difference between the pipes and surrounding environment.

The possibility of harvesting energy from nature is fascinating but the cost issues of deploying such a technology shall be considered as well.

A scientific approach to implementing this feature for low electronic applications has to evaluate it and decide if energy scavenging proves better results in both technical and economical aspects in comparison with other technologies.

The research which have been carrying out in different microelectronics fields such as transmitter, microcontroller, storage schemes along with the advancements in energy harvesting technology will demonstrate more compelling results in the future.

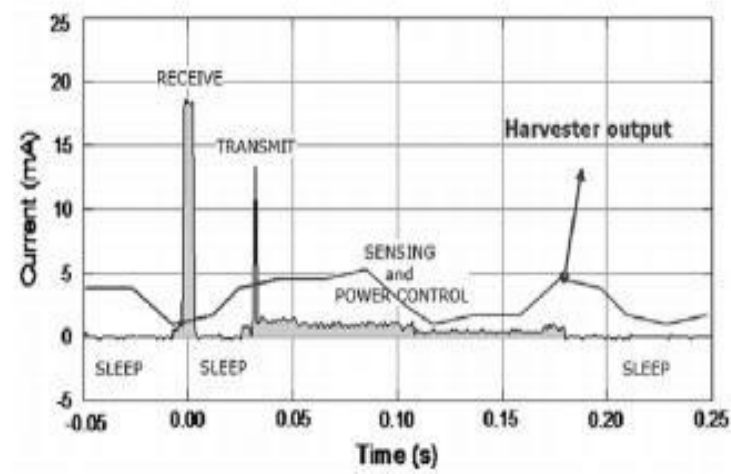

Fig. 5. In some cases the amount of harvested energy is not enough to provide the necessary power for the transceiver module [39]

\section{ACKNOWLEDGEMENTS}

The author would like to express the deep gratitude to Prof. Alexander Baranov from "MATI"- Russian State Technological University for the help in the manuscript preparation and useful discussion. This work was supported in the frame work of Russian Federal Program Grant No. 14.577.21.0022.

\section{References}

[1] A. Somov, A. Baranov, A. Savkin, D. Spirjakin, A. Spirjakin, R. Passerone Development of wireless sensor network for combustible gas monitoring Sensors and Actuators A: Physical, vol. 171, pp. 398 - 405, 2011. DOI: 10.1016/j.sna.2011.07.016.

[2] V.G. Gasull1, D.F. Larios1, J. Barbancho, C. León1 and M.S. Obaidat "A Wildfire Prediction Based on Fuzzy Inference System for Wireless Sensor Networks", in E-Business and Telecommunications, vol. 314. Mohammad S. Obaidat, José L. Sevillano, Joaquim Filipe, Ed. Berlin Heidelberg: Springer, 2012, pp 43-59, DOI: 10.1007/978-3-64235755-8_4.

[3] A. Somov, D. Spirjakin, M. Ivanov, I. Khromushin, R. Passerone, A. Baranov, and A. Savkin "Combustible Gases and Early Fire Detection: an Autonomous System for Wireless Sensor Networks: an Autonomous System for Wireless Sensor Networks", Proceedings of the e-Energy 2010 - 1st Int'l Conf. on Energy-Efficient Computing and Networking. pp. 85 -93 . DOI: 10.1145/1791314.1791327.

[4] A. Volokitina, M. Sofronov, and T. Sofronova, "Topical scientific and practical issues of wildland fire problem," Mitigation and Adaptation Strategies for Global Change journal (Springer Netherlands), vol. 13, no. 7, pp. 661-674, August 2008. DOI: 10.1007/s11027-007-9120-7.

[5] A. Enis Cetin, D. Akers, I. Aydin, N. Dogan, O. Günay, B. Ugur Toreyin "Using Surveillance Systems for Wildfire Detection", www.firefighternation.com/article/wildland-urban-interface/ usingsurveillance-systems-wildfire-detection [Jun. 5, 2013].

[6] I. Yoon, D. K. Noh, D. Lee, R. Teguh, T. Teguh and H. Shin, "Reliable Wildfire Monitoring with Sparsely Deployed Wireless

TABLE V.

CHARACTERISTICS OF BATTERIES AND SUPERCAPACITORS [39],[41],[42],,[43],[44],[45],[46]

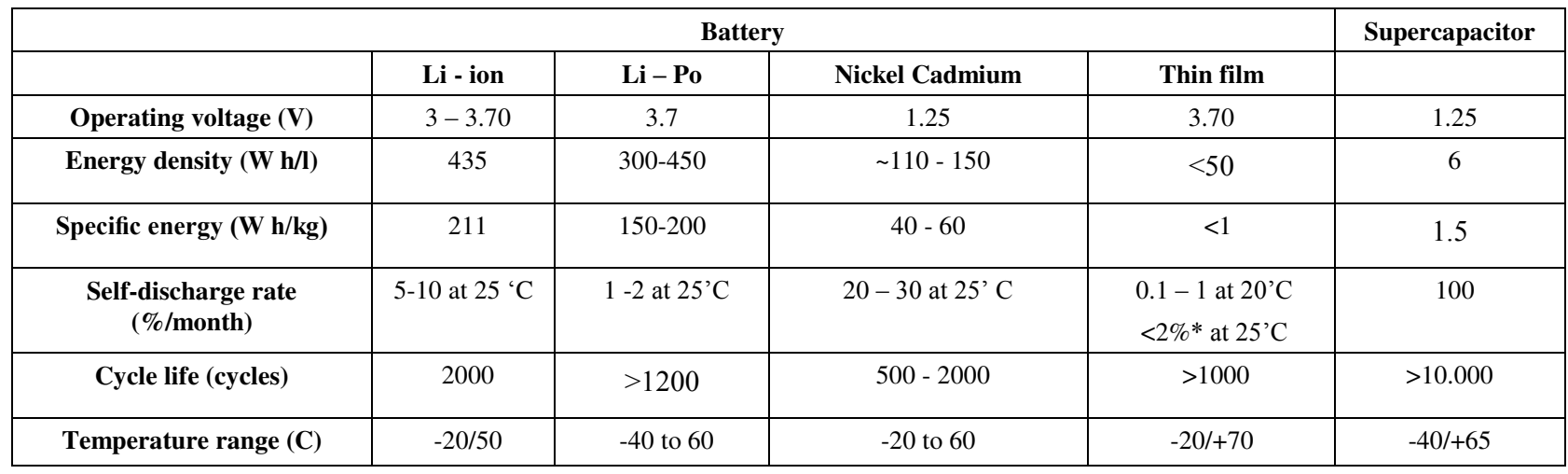

* According to Ref. [46], a battery with a $2 \mu \mathrm{m}$-thick cathode, can output the mentioned value. 
Sensor Networks, " in Proc. IEEEAINA, pp. 460-466, 2012,

DOI: 10.1109/AINA.2012.107.

[7] Y. Li, Z. Wang, and Y. Song, "Wireless sensors network design for wildfire monitoring," in Proc. of 6th IEEE World Congress on Intelligent Control and Automation, Jun. 2006, pp. 109 - 113, DOI: 10.1109/WCICA.2006.1712372.

[8] S. So and G. Wysocki, "Ultra efficient laser spectroscopic trace-gas sensors for sensor networks and portable chemical analysis," Innovation Forum 2009, Princeton school of engineering and applied science, May, 2009.

[9] Andrey Somov, Alexander Baranov, Denis Spirjakin, Andrey Spirjakin, Vladimir Sleptsov, Roberto Passerone, "Deployment and evaluation of a wireless sensor network for methane leak detection". Sensors and Actuators A: Physical Physical- vol. 202, pp. 217-225, November 2013, DOI: 10.1016/j.sna.2012.11.047.

[10] Seah, W.K.G., Zhi Ang Eu, Tan, H. "Wireless sensor networks powered by ambient energy harvesting (WSN-HEAP)-Survey and challenges," in Wireless VITAE 2009, May 2009, pp. 1-5, DOI: 10.1109/WIRELESSVITAE.2009.5172411.

[11] J. Puchyova, M. Kochlan, M. Hodon "Development of Special Smartphone-Based Body Area Network: Energy Requirements" in Proc. Federated Conference on Computer Science and Information Systems (FedCSIS), 2013, pp. 895 - 900.

[12] A. Somov, A. Baranov, A. Savkin, M. Ivanov, L. Calliari, R. Passerone, E. Karpov, and A. Suchkov, "Energy-Aware Gas Sensing Using Wireless Sensor Networks", in Wireless Sensor Networks Series: Lecture Notes in Computer Science, vol. 7158. Gian Pietro Picco, Wendi Heinzelman, Ed. Berlin Heidelberg: Springer, 2012, pp.245-260, DOI: 10.1007/978-3-642-28169-3_16.

[13] British Standard Institution. Electrical apparatus for the detection of combustible gases in domestic premises. Test methods and performance requirements. 2000.

[14] J. Paulo and P.D. Gaspar "Review and Future Trend of Energy Harvesting Methods for Portable Medical Devices" Proceedings of the World Congress on Engineering, pp. 909-914, 2010.

[15] C. Mathna, T.O Donnell, R.V. Martinez - Catala, J. Rohan, and B.O Flynn, "Energy scavenging for long - term deployable wireless sensor networks", Elsevier: Talanta, vol. 75, no.3, pp. 613 -623, 2008, DOI: 10.1016/j.talanta.2007.12.021.

[16] Murugavel Raju, Mark Grazier, Texas Instrument, http://www.ti.com.cn/cn/lit/wp/slyy018a/slyy018a.pdf [Apr. 2010].

[17] P. Jayarama Reddy. Solar Power Generation: Technology, New Concepts \& Policy. Leiden, The Netherlands: CRC Press/Balkema, 2012, pp. 2-3.

[18] A. R. Jha "Solar Cell Technology and Applications",Boca Raton, FL: CRC Press, 2009 p.158.

[19] D. Dondi, A. Bertacchini, L. Larcher, P. Pavan, D. Brunelli, and L. Benini, "A solar energy harvesting circuit for low power applications," in Proc. IEEE International Conf. on Sustainable Energy Technologies (ICSET), Nov. 2008, pp. 945-949, DOI: 10.1109/ICSET.2008.4747143.

[20] M. Kochlan, P. Sevcik, "Supercapacitor power unit for an eventdriven wireless sensor node" in Proc. Federated Conference on Computer Science and Information Systems (FedCSIS), 2012, pp. $791-796$

[21] Dongsheng Ma, Rajdeep Bondade, "Reconfigurable SwitchedCapacitor Power Converters: Principles and Designs for Self-Powered Microsystems" New York: Springer, 2011, p. 3, DOI: 10.1007/978-14614-4187-8.

[22] Zekai Sen "Solar Energy Fundamentals and Modeling Techniques: Atmosphere, Environment, Climate Change and Renewable Energy", 2008, Springer, p. 36, DOI: 10.1007/978-1-84800-134-3.

[23] Z. Abdin, M.A.Alim, R.Saidur, M.R.Islam, W.Rashmi, S.Mekhilef, A.Wadi "Solar energy harvesting with the application of nanotechnology", Elsevier: Renewable and Sustainable Energy Reviews, vol. 26, 2013, p. 843, DOI: 10.1016/j.rser.2013.06.023.

[24] Stephen Beeby, Neil M. White "Energy Harvesting for Autonomous Systems", Norwood, MA: ,2010, pp 99-100.

[25] Alper Erturk, Daniel J. Inman "Piezoelectric Energy Harvesting", UK: John Wiley \& Sons, 2011, pp.2-3.

[26] Waldemar Karwowski, William S. Marras "The Occupational Ergonomics Handbook", Boca Raton, FL: CRC Press, 1998, p. 570.
[27] Joshua R. Smith, "Range Scaling of Wirelessly Powered Sensor Systems" in Wirelessly Powered Sensor Networks and Computational RFID, Joshua R. Smith, Ed. New York: Springer, 2013, p.3, DOI: 10.1007/978-1-4419-6166-2.

[28] Harry Ostaffe, Jason Tollefson "Harvested RF Powers Remote Sensors,"[Dec.12, 2014] http://www.digikey.com/enUS/articles/techzone/2011/dec/harvested-rf-powers-remote-sensors.

[29] R. Vias, H. Nishimoto, M. Tentzeris, Y. Kawahara, T. Asami, "A Battery-Less, Energy Harvesting Device for Long Range Scavenging of Wireless Power from Terrestrial TV Broadcasts," IEEE 2012 IMS Digest, Montreal, Canada, June 2012, DOI: 10.1109/MWSYM.2012.6259708.

[30] Kenneth Kroos, Merle Potter, "Thermodynamics for Engineers", Stamford CT: Cengage Learning, 2014, p.472.

[31] V. Çağrı Güngör, Gerhard P. Hancke, "Industrial Wireless Sensor Networks: Applications, Protocols, and Standards", Boca Raton, FL: CRC Press, 2013, p.127.

[32] Tony Armstrong "Aircraft Structures Take Advantage of Energy Harvesting Implementations", http://www.eetimes.com/document.asp?doc_id=1278767, [May. 11, 2011].

[33] J.W. Park, H.Jo Jung, , H. Jo and B. F. Spencer, Jr. "Feasibility Study of Micro-Wind Turbines for Powering Wireless Sensors on a CableStayed Bridge" MDPI: Energies, vol. 5, 2012, pp. 3450-3464. DOI:10.3390/en5093450

[34] Hermann-Josef Wagner, Jyotirmay Mathur "Introduction to Wind Energy Systems: Basics, Technology and Operation", Berlin Heidelberg: Springer, 2013, p.3, DOI: 10.1007/978-3-642-32976-0

[35] Huaping Yu, Mei Guo, "An effective oil and gas pipeline monitoring systems based on wireless sensor networks", International Conference on Information Security and Intelligence Control (ISIC),2012, pp. 178 -181 .

[36] M. Reyer, S. Hurlebaus, John Mander, Osman E. Ozbulut, "Design of a Wireless Sensor Network for Structural Health Monitoring of Bridges" Wireless Sensor Networks and Ecological Monitoring Smart Sensors, Measurement and Instrumentation" in Wireless Sensor Networks and Ecological Monitoring, v.3, Subhas C Mukhopadhyay, Joe Air Jiang, Ed. Berlin Heidelberg: Springer, 2013, pp 195-216, DOI: $10.1007 / 978-3-642-36365-8 \_8$.

[37] Jiaonnong Cao and Xuefeng Liu, "Structural Health Monitoring Using Wireless Sensor Networks", in Mobile and Pervasive Computing in Construction Chimay J. Anumba, Xiangyu Wang, ,Ed. UK, 2012, John Wiley \& Sons, p.224, DOI: 10.1002/9781118422281.ch11.

[38] Edgar H. Callaway, Jr., "Wireless Sensor Networks: Architectures and Protocols", Boca Raton, FL: CRC Press, 2004, p.140.

[39] R.J.M. Vullers, R. van Schaijka, I. Doms, C. Van Hoof, R. Mertens, "Micropower energy harvesting", Elsevier: Solid-State Electronics,vol. 53, 2009. pp. 684-693, DOI: 10.1016/j.sse.2008.12.011.

[40] D. Kelaidonis, A. Somov, V. Foteinos, G. Poulios, V. Stavroulaki, P. Vlacheas, P. Demestichas, A. Baranov, A. Biswas, and R. Giaffreda, "Virtualization and cognitive management of real world objects in the internet of things" in IEEE International Conference on Green Computing and Communications (GreenCom), 2012, pp. 187-194. DOI: $10.1109 /$ GreenCom.2012.37.

[41] Roland Büchi. Radio Control with $2.4 \mathrm{GHz}$. Norderstedt: Books on Demand, 2014, p. 26.

[42] Pei Zheng, Lionel Ni. Smart Phone and Next Generation Mobile Computing. San Francisco CA: Morgan Kaufmann, 2006. p. 86,

[43] Petar J. Grbovic. Ultra Capacitors in Power Conversion Systems: Analysis, Modeling and Design in Theory and Practice. West Sussex, UK: Wiley - IEEE Press. 2014. p. 17.

[44] Frank R. Spellman Handbook of Water and Wastewater Treatment Plant Operations. Boca Raton, FL: CRC Press. 2013. p. 348.

[45] A. Manthiram. "Materials Aspects: An Overview" in Lithium Batteries: Science and Technology. G.A. Nazri, G. Pistoia, Ed. Springer US, 2003, p. 4, DOI: 10.1007/978-0-387-92675-9.

[46] N.J. Dudney "Solid-State Thin-Flm Rechargeable Batteries". Materials Science and Engineering B, vol. 116, pp. 245 - 249, Feb. 2005, DOI:10.1016/j.mseb.2004.05.045. 